Pure Appl. Chem., Vol. 73, No. 5, pp. 761-770, 2001.

(C) 2001 IUPAC

\title{
Treatment of Tunisian salt lakes using solubility phase diagrams*
}

\author{
Najia Kbir-Ariguib $^{\dagger}$, Dalila Ben Hassan Chehimi, and Lotfi Zayani \\ Institut National de Recherche Scientifique et Technique, Borg Cedria P.O. Box 95, \\ Hammam-Lif, 2050 Tunisia
}

\begin{abstract}
The Tunisian salt lakes are considered as an important materials resource useful for industry and agriculture. They are called sebkhat or chott, and they cover a large part of Tunisian land. Their brines correspond to the quinary system: $\mathrm{Na}^{+}, \mathrm{K}^{+}, \mathrm{Mg}^{2+} / \mathrm{Cl}-$, $\mathrm{SO}_{4}{ }^{2-}-\mathrm{H}_{2} \mathrm{O}$. In the first part of this paper, a short description and abstracted geochemical and economical data about some Tunisian salt lakes are given. In the second part, the fitting equations used for modeling the quinary system are established and applied to the subsystems $\mathrm{NaCl}-\mathrm{KCl}-\mathrm{H}_{2} \mathrm{O}, \mathrm{NaCl}-\mathrm{MgCl}_{2}-\mathrm{H}_{2} \mathrm{O}, \mathrm{KCl}-\mathrm{MgCl}_{2}-\mathrm{H}_{2} \mathrm{O}$, and to $\mathrm{NaCl}-\mathrm{Na}_{2} \mathrm{SO}_{4}-\mathrm{H}_{2} \mathrm{O}$, $\mathrm{KCl}-\mathrm{K}_{2} \mathrm{SO}_{4}-\mathrm{H}_{2} \mathrm{O}, \mathrm{Na}_{2} \mathrm{SO}_{4}-\mathrm{K}_{2} \mathrm{SO}_{4}-\mathrm{H}_{2} \mathrm{O}$. The coherence between the calculated and the experimental diagrams is discussed.
\end{abstract}

\section{INTRODUCTION}

An important area of Tunisia is covered by salt lakes called sebkhat or chott. They are located all over the country. Meanwhile, they are more concentrated in the south (Fig. 1).

The most famous Tunisian salt lakes are: Chott el Jerid, in the south, appearing as the biggest one, Sebkhat el Melah of Zarsis and Sebkhat el Adhibate in the south east, and Sebkhat Om el Khialate in the Saharan part of the country.

The Tunisian sebkhats and chotts are different from the usual salt lakes or closed seas. They appear as areas covered by a salt crust hiding a spongy soil soaked with briny water. Sometimes in winter when much rain falls they acquire the aspect of lakes for some months.

These salty lakes contain similar ions to the seas, but the concentration of salts is 10 to 20 times more important than in sea water and varies between 250 and $330 \mathrm{~g} / \mathrm{l}$. They can be a significant resource of useful salts.

The major elements contained in a sebkhat or a chott are sodium, potassium, magnesium, calcium, chloride, sulfate, and carbonate. Other elements such as lithium, boron, bromine, iodine, etc. are present but at a lower concentration; they are the minor elements. There are also many other elements but as traces.

\section{GEOCHEMICAL CHARACTERISTICS OF SOME TUNISIAN SALT LAKES [1]}

Chott el Jerid covers $5000 \mathrm{~km}^{2}$. Recent geological studies proved that this chott is not the vestige of a previous Saharan sea as presented by some geologists of the beginning of the $20^{\text {th }}$ century. Recent studies have shown that its solid salts and brine come from the geological formations of the surrounding mountains. It contains a total stock of brine estimated to be 5 billion $\mathrm{m}^{3}$. Its salinity average is $330 \mathrm{~g} / \mathrm{l}$ (Table 1), but its composition is heterogeneous. It is more sulfated on the east side and more concen-

\footnotetext{
*Lecture presented at the $9^{\text {th }}$ IUPAC International Symposium on Solubility Phenomena ( $9^{\text {th }}$ ISSP), Hammamet, Tunisia, 25-28 July 2000. Other presentations are published in this issue, pp. 761-844.

${ }^{\dagger}$ Corresponding author: E-mail: ariguib@planet.tn
} 


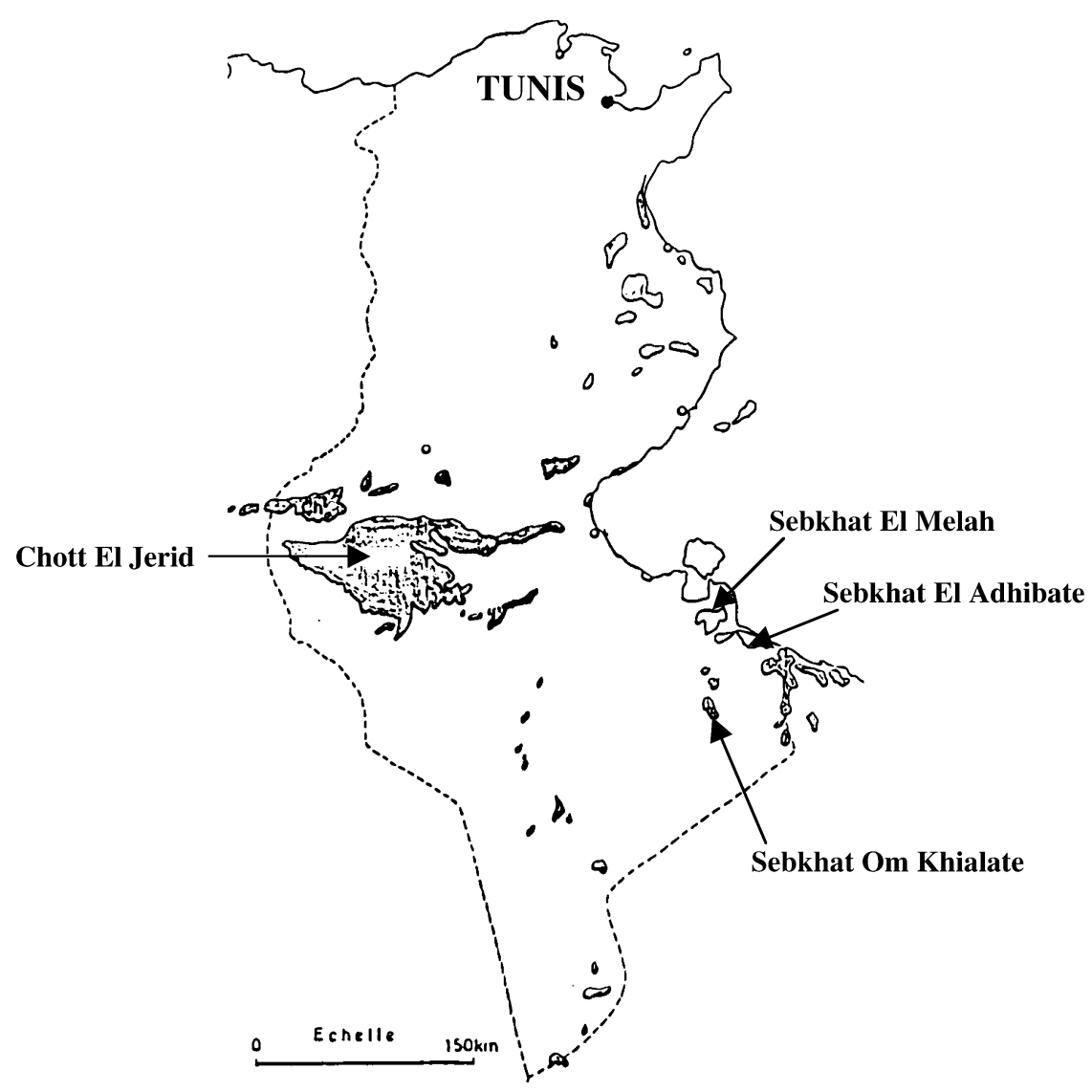

Fig. 1 Location of some salt lakes on the map of Tunisia.

trated in potassium on the west side. Chott el Jerid seems to be interesting because of its potassium sulfate content.

Sebkhat el Melah of Zarzis has the aspect of a large plain $\left(150 \mathrm{~km}^{2}\right)$ covered with salt and separated from the sea by a small offshore bar. Sometimes, it communicates with the sea. There are holes in the surface from which the brine gushes out. Each hole is a kind of well of 6 to $8 \mathrm{~m}$ deep. The brine of this sebkhat is homogeneous. It contains more magnesium, potassium, and chloride than brine from the other sebkhats (Table 1).

Sebkhat el Adhibate is located at the south east of the country; it covers $125 \mathrm{~km}^{2}$. It is separated from the sea by a big depression and it is at the level $-1 \mathrm{~m}$. This sebkhat isn't as saturated as the others. Its major element is sodium (Table 1).

Sebkhat om Khialate is in the south east of Tunisia, in the desert region. Its area is $75 \mathrm{~km}^{2}$. It is covered by a thin crust a few decimeters thick containing a mixture of halite, gypsum, and thenardite $\left(\mathrm{Na}_{2} \mathrm{SO}_{4}\right)$ (Table 1). In the higher levels of the sebkhat the thenardite precipitates alone.

Table 1 shows that the salt lakes cited can be an important resource for interesting salts and that the concentration of the major ions varies from one brine to another. 
Table 1 Average composition, g/l of Tunisian sebkhat and chott brines.

\begin{tabular}{lrrrrrc}
\hline Ions & $\mathrm{Na}^{+}$ & $\mathrm{K}^{+}$ & $\mathrm{Ca}^{2+}$ & $\mathrm{Mg}^{2+}$ & $\mathrm{Cl}^{-}$ & $\mathrm{SO}_{4}^{2-}$ \\
\hline Chott el Jerid & 100 & 9.0 & 0.7 & 12 & 197 & 12 \\
Sebkhat el Melah & 45 & 7.7 & 0.2 & 50 & 200 & 28 \\
Sebkhat el Adhibate & 88 & 3.6 & 1.0 & 12.6 & 150 & 37 \\
Sebkhat om Khialate & 43 & 0.8 & 0.4 & 3.3 & 24 & 74 \\
\hline
\end{tabular}

\section{BIBLIOGRAPHICAL DATA}

Since the beginning of the $19^{\text {th }}$ century the sebkhats have caught the attention of scientists and economists. The geological and economical studies began early in the $20^{\text {th }}$ century. The main questions were:

- How were these brines formed?

- Do they communicate with the sea?

- What is their composition?

- Do they contain important salts?

- How could these be extracted?

The first work was done on the Sebkhat el Melah of Zarzis [2-6,8,9,14-18]. Then, several Tunisian researchers began to work on Tunisian brines other than that of Sebkhat el Melah. Their studies did not only concern geological aspects but were extended to the study of phase diagrams related to the system representing the brines [18-24].

Many present studies involve modeling of phase diagrams [1,26,27,30,33,34] and extraction of interesting salts $[28,29,31,32]$.

The preceding data show that the Tunisian salt lakes brines still interest many scientists. This can be explained by the economical value of the salts contained in these brines, for example: potassium sulfate and chloride for agriculture, sodium sulfate for glass and detergents industries, magnesium chloride for fireproof materials and pharmaceutical products, sodium chloride for food and for other industries.

Therefore, the chotts and sebkhats containing big deposits of salts are expected to play an important role in the economic sector of Tunisia.

However, the extraction of salts remains difficult, because of the lack of reliable models of the brines and of literature describing the methods which should be adapted in each case.

\section{COMPILATIONS RELEVANT TO THE QUINARY SYSTEM REPRESENTING THE BRINES}

The best way to find how to extract particular salts is to define their precipitation fields in the phase diagram representing the system containing the major elements of the brines: $\mathrm{Na}^{+}, \mathrm{K}^{+}, \mathrm{Mg}^{2+}, \mathrm{Ca}^{2+}, \mathrm{Cl}^{-}$, $\mathrm{SO}_{4}{ }^{2-}, \mathrm{CO}_{3}{ }^{2-}, \mathrm{H}_{2} \mathrm{O}$. This system contains seven elements plus water. It is so complicated that it has to be simplified. As the element calcium is in the presence of sulfate and carbonate, its concentration in the solution is low, so it can be considered as a minor element. As the solvent is water, in well-defined conditions, at each temperature, the system can be considered as a reciprocal quinary one with sodium, potassium, magnesium, chloride, and sulfate in water.

Representing this system is so complicated that many authors considered only the subsystem where the solutions are saturated with respect to sodium chloride. But if the industrial process has to eliminate sodium chloride from the final product the equilibria between all phases of the whole system must be known. 
Compilations related to quinary systems date from the beginning of the $20^{\text {th }}$ century: Van't Hoff and Meyerhoffer [10], d'Ans [7], Landolt-Börnstein [11], Stephen and Stephen [12] and Linke [13].

But these compilations are not easy to use, the representation of a quinary system diagram is very specific, and the data are widely scattered and are given in different units. At present, many organizations are looking for a solution. IUPAC, for example, especially Commission V.8, is preparing volumes containing evaluated data on the sea water systems [25]. The COPERNICUS project will lead to publishing of evaluated data on the Black Sea system. A book dealing with the extraction of salts from Tunisian brines will also soon be published.

\section{MODELING OF PHASE DIAGRAMS APPLIED TO THE QUINARY SYSTEM}

A rational exploitation of the system $\mathrm{Na}^{+}, \mathrm{K}^{+}, \mathrm{Mg}^{2+}, \mathrm{Cl}^{-}, \mathrm{SO}_{4}{ }^{2-}, \mathrm{H}_{2} \mathrm{O}$, for industrial or fundamental application, requires reliable solubility data and the determination of the sequence of crystallization during evaporation or cooling of a brine, the calculation of yield, recycling rate, etc. It is based on convenient fitting equation allowing the calculation of solubility in a large range of temperature and composition.

The water-salt binary systems involving stoichiometric solid phases can be fully described with a semiempirical model derived from the thermodynamic conditions of equilibrium. The model complies with all thermodynamic constraints of the system and requires a small number of adjustable coefficients.

The same procedure can be used for the calculation of a complex system.

The solubility of a salt in saturated solution is described in terms of heterogeneous reaction between solid and liquid. An equation of the solubility field is established for each solid and each limiting or intermediate phase of a multicomponent aqueous salt system.

The model supposes that solid phases are stoichiometric and that the solution is a strong electrolyte. It includes all subsystems.

The equation of solubility surface of stoichiometric solid phases can be written as follows:

$$
U-U^{0}=A(\sigma) / T+B(\sigma) \ln T+C(\sigma)+D(\sigma) T+\ldots
$$

$U$ represents the logarithm of solubility product of the species in equilibrium with liquid and $U^{0}$ is the same quantity considered at stoichiometry:

$$
U=\sum_{i} v_{i} \ln x_{i} \quad U^{0}=\sum_{i} v_{i} \ln x_{i}^{0} \quad \text { with } \quad x_{i}^{0}=v_{i} / \sum_{j} v_{j}
$$

It is reduced to $\ln \left(x_{i} / x_{i}^{0}\right)$ if the solubility surface concerns a molecular compound (water).

When the order of a system is more than 2 the coefficients $A, B, C, \ldots$ are no longer independent of composition and several empirical expressions have been tried out and compared. Actually, two polynomial series that fill almost all criteria of selection are proposed.

The first equation has been tested on simple systems such as $\mathrm{NaCl}-\mathrm{KCl}-\mathrm{H}_{2} \mathrm{O}$, $\mathrm{NaCl}-\mathrm{MgCl}_{2}-\mathrm{H}_{2} \mathrm{O}$, and $\mathrm{KCl}-\mathrm{MgCl}_{2}-\mathrm{H}_{2} \mathrm{O}$. The coefficients along the solubility domain of a compound are:

$$
A=\sum\left[\frac{v_{i}}{1-x_{i}} \sum_{j} a_{i j} x_{j}+\left(\frac{v_{i}}{1-x_{i}}\right)^{2} \sum_{j} \sum_{k} a_{i j k} x_{j} x_{k}+\ldots\right]
$$

$v_{i}, x_{i}$ are respectively the stoichiometric coefficient and the mole fraction of constituent $i$ (salt or water) in the compound under consideration, $a_{i j}, a_{i j k}, \ldots$ are adjustable coefficients; $j, k, \ldots$ are assumed to be different from $i$. 
Figure 2 representing the calculated diagram of the system $\mathrm{NaCl}-\mathrm{KCl}-\mathrm{H}_{2} \mathrm{O}$ in the temperature range -30 to $140{ }^{\circ} \mathrm{C}$, shows that the calculated mono-variant line separating the fields of $\mathrm{KCl}$ and $\mathrm{NaCl}$ is in very good agreement with the experimental data.

For the system $\mathrm{NaCl}-\mathrm{MgCl}_{2}-\mathrm{H}_{2} \mathrm{O}$ (Fig. 3), only the curve separating the domains of $\mathrm{NaCl}$ and $\mathrm{MgCl}_{2} \cdot 6 \mathrm{H}_{2} \mathrm{O}$ has been calculated in the range of temperature 0 to $115^{\circ} \mathrm{C}$. It represents an average between the scattered experimental points.

The experimental data and the calculated curves (Fig. 4) of the system $\mathrm{KCl}-\mathrm{MgCl}_{2}-\mathrm{H}_{2} \mathrm{O}$ show a good agreement between the experimental data and the calculated curve separating the fields of $\mathrm{KCl}$ and $\mathrm{KCl} \mathrm{MgCl}_{2} \cdot 6 \mathrm{H}_{2} \mathrm{O}$ from 0 to $125^{\circ} \mathrm{C}$.

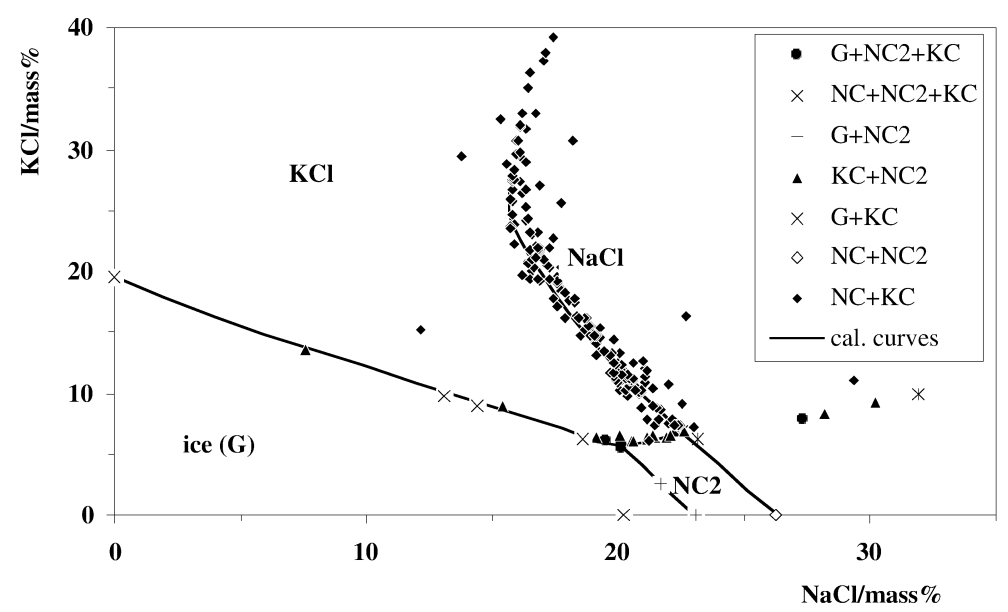

Fig. 2* System $\mathrm{NaCl}-\mathrm{KCl}-\mathrm{H}_{2} \mathrm{O}$.

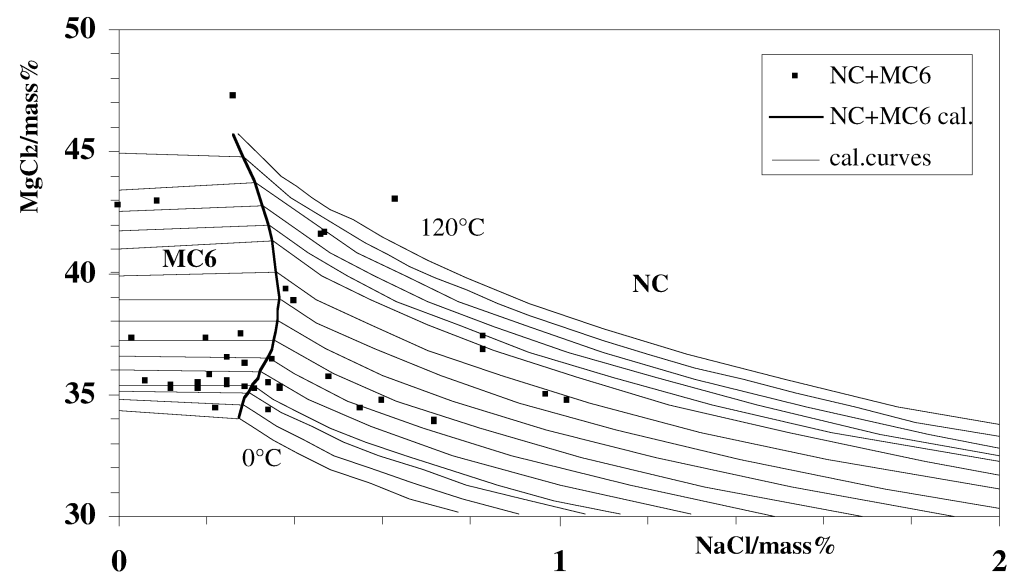

Fig. 3* System $\mathrm{NaCl}-\mathrm{MgCl}_{2}-\mathrm{H}_{2}$. 


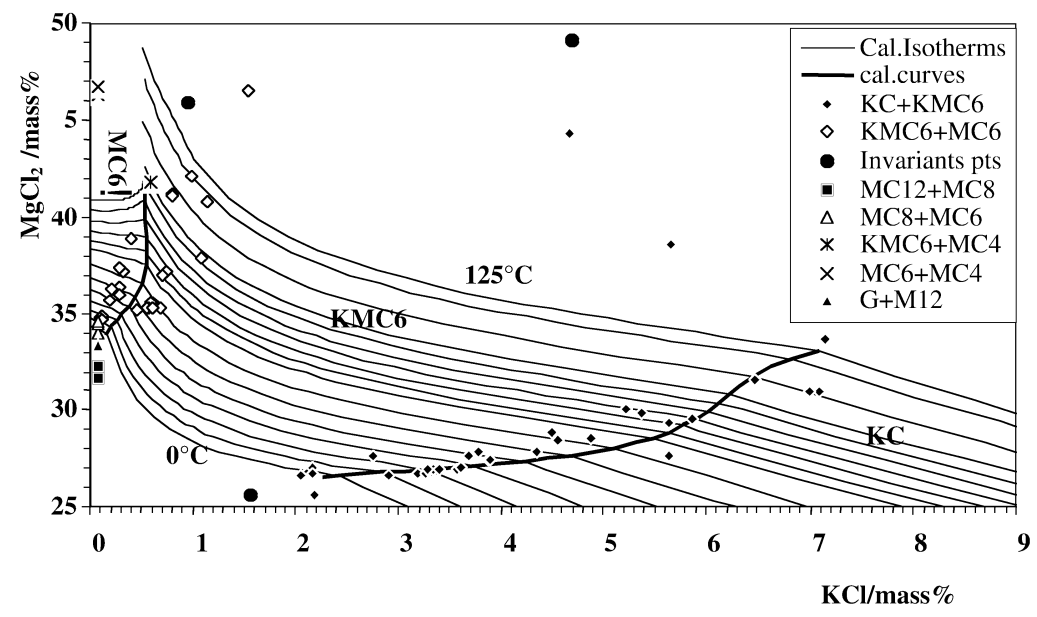

Fig. 4* System $\mathrm{KCl}-\mathrm{MgCl}_{2}-\mathrm{H}_{2} \mathrm{O}$ (mass \%).

The application of the first equation to reciprocal systems and to the solubility range of ternary or more complex salts is not easy. However, the second equation is more convenient. The ions are separated in cations $\mathrm{N}\left(\mathrm{Na}^{+}\right), \mathrm{K}\left(\mathrm{K}^{+}\right), \mathrm{M}\left(\mathrm{Mg}^{2+}\right)$, and anions $\mathrm{C}\left(\mathrm{Cl}^{-}\right), \mathrm{S}\left(\mathrm{SO}_{4}{ }^{2-}\right)$. The general equation of the solubility field of a compound in the quinary system is written as follows

$$
A(\sigma)=\sum_{i} \sum_{j} X_{i} Y_{j}\left(a^{i j}(\sigma)+\sum_{n} \sum_{k} U_{k}^{n}\left(a_{n}^{i j k}(\sigma)+\sum_{p} \sum_{l} V_{l}^{p}\left(a_{n p}^{i j k l}(\sigma)+\sum_{q} W_{m}^{q} a_{n p q}^{i j k l m}(\sigma)\right)\right)\right)
$$

where $A(\sigma)$ is an adjustable coefficient of the solid-phase solubility field

The former relation includes the solubility fields of all subsystems. $a^{i j}(\sigma)$ is the coefficient of species $\sigma$ in the binary system $(i, j)-\mathrm{H}_{2} \mathrm{O} . a^{i j}(\sigma)=0$ when $i$ and $j$ are not constituents of $\sigma$, except for the solubility field of ice where $a^{i j}(\mathrm{H}) \neq 0$ for all binary subsystems. $\mathrm{a}_{n}{ }^{i j k}(\sigma)$ is the coefficient of $U_{k}{ }^{n}$ in the ternary system $(i, j, k)-\mathrm{H}_{2} \mathrm{O}$, etc. The obtained analytical expression has been tested on several systems. The model gives a good description of the solubility surfaces of most of the solid phases in the two kinds of systems simple and reciprocal.

Three examples of calculated ternary systems belonging to the reciprocal quaternary diagram $\mathrm{Na}^{+}, \mathrm{K}^{+} / \mathrm{Cl}^{-}, \mathrm{SO}_{4}{ }^{2-} \mathrm{H}_{2} \mathrm{O}$ are presented in this paper:

The first one, $\mathrm{NaCl}-\mathrm{Na}_{2} \mathrm{SO}_{4}-\mathrm{H}_{2} \mathrm{O}$ (Fig. 5), treated between 10 and $150{ }^{\circ} \mathrm{C}$ contains only three domains easy to exploit and presents three mono-variant lines. In this diagram, the experimental data and the calculated curves are in good agreement.

The second system is $\mathrm{KCl}-\mathrm{K}_{2} \mathrm{SO}_{4}-\mathrm{H}_{2} \mathrm{O}$ (Fig. 6). It is calculated in the temperature range 0 to $100{ }^{\circ} \mathrm{C}$. It has only one mono-variant line separating the domains of $\mathrm{KCl}$ and $\mathrm{K}_{2} \mathrm{SO}_{4}$. The calculated curve is coherent with the experimental data.

The last one is $\mathrm{Na}_{2} \mathrm{SO}_{4}-\mathrm{K}_{2} \mathrm{SO}_{4}-\mathrm{H}_{2} \mathrm{O}$ (Fig. 7). It has been studied between 0 and $150{ }^{\circ} \mathrm{C}$. The salts $\mathrm{K}_{2} \mathrm{SO}_{4}, \mathrm{Na}_{2} \mathrm{SO}_{4} 3 \mathrm{~K}_{2} \mathrm{SO}_{4}$, and $\mathrm{Na}_{2} \mathrm{SO}_{4} \cdot 10 \mathrm{H}_{2} \mathrm{O}$ have well-defined domains, and their calculated intersecting curves are in agreement with those of the literature. But the mono-variant line separating the fields of $\mathrm{Na}_{2} \mathrm{SO}_{4}$ and $\mathrm{Na}_{2} \mathrm{SO}_{4} 3 \mathrm{~K}_{2} \mathrm{SO}_{4}$ is not well defined probably because of the retrograde solubility exhibited by $\mathrm{Na}_{2} \mathrm{SO}_{4}$.

Other diagrams belonging to the quinary system calculated by the first or the second equation are presented in the Table 2 .

For some other systems, solubility fields could not be evaluated due to the small number and low quality of the data available. 


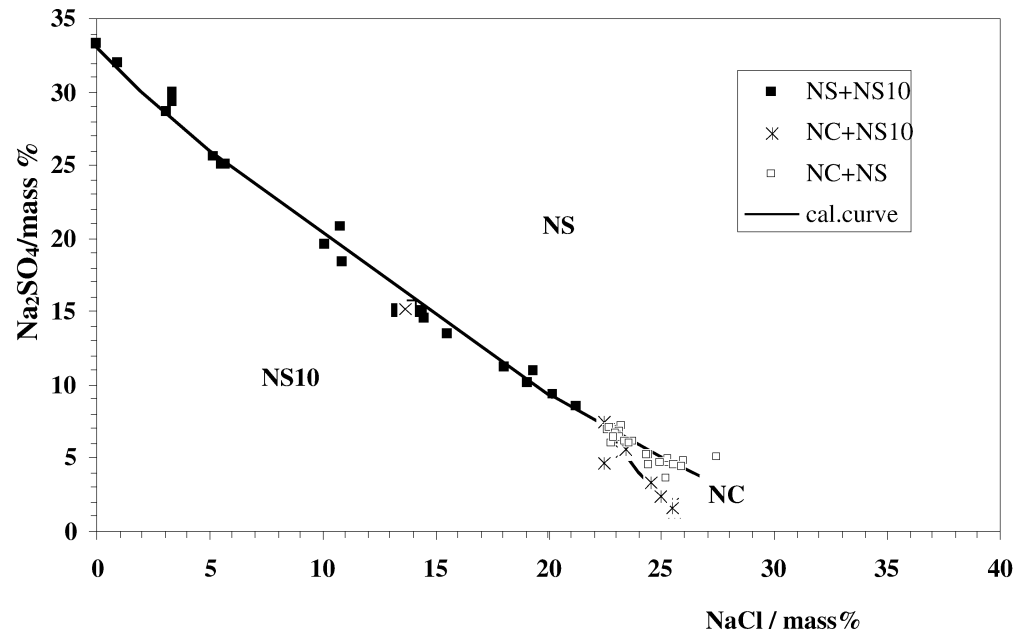

Fig. 5* System $\mathrm{NaCl}-\mathrm{Na}_{2} \mathrm{SO}_{4}-\mathrm{H}_{2} \mathrm{O}$.

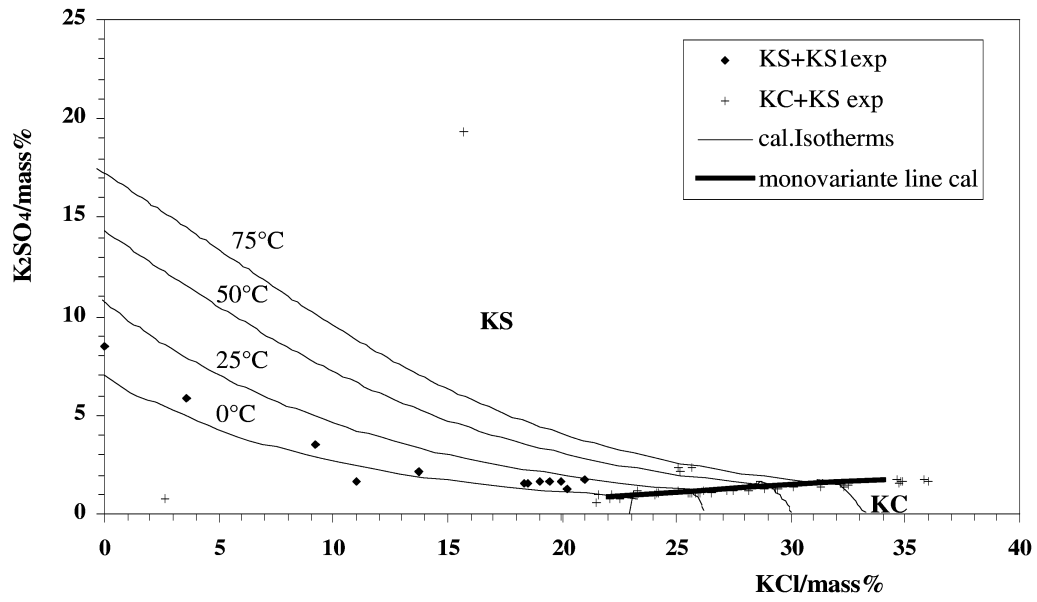

Fig. 6* System $\mathrm{KCl}-\mathrm{K}_{2} \mathrm{SO}_{4}-\mathrm{H}_{2} \mathrm{O}$ (mass \%).

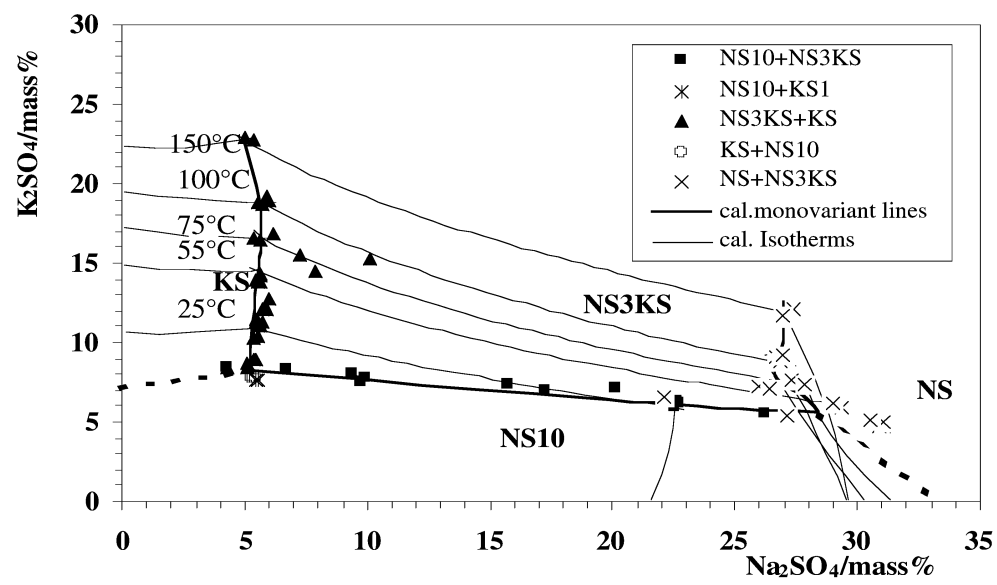

Fig. $7 * \mathrm{Na}_{2} \mathrm{SO}_{4}-\mathrm{K}_{2} \mathrm{SO}_{4}-\mathrm{H}_{2} \mathrm{O}$.

(C) 2001 IUPAC, Pure and Applied Chemistry 73, 761-770 
When the experimental solubility data are sufficiently well defined, the second analytical expression allows a critical evaluation of the data collected from various sources. It also confirms the nature of the solid phases determined by different methods.

The conclusion of this study is that a good knowledge of the solubility diagrams related to the quinary system $\mathrm{Na}^{+}, \mathrm{K}^{+}, \mathrm{Mg}^{2+}, \mathrm{Cl}^{-}, \mathrm{SO}_{4}{ }^{2-}, \mathrm{H}_{2} \mathrm{O}$, could help in the treatment of the Tunisian salt lakes brines for extraction of useful salts. A lot of works have been carried out on the sebkhats and chotts, but there is still a lot to do for their valorization.

Table 2 Calculated solubility curves in the quinary diagram representing the brines.

\begin{tabular}{|c|c|c|}
\hline Systems & Calculated curves & $\begin{array}{l}\text { Calculated and } \\
\text { experimental curves }\end{array}$ \\
\hline $\mathrm{NaCl}-\mathrm{H}_{2} \mathrm{O}[24]$ & $\mathrm{H}_{2} \mathrm{O} ; \mathrm{NaCl} ; \mathrm{NaCl} .2 \mathrm{H}_{2} \mathrm{O}$ & Coherent \\
\hline $\mathrm{KCl}-\mathrm{H}_{2} \mathrm{O}[24]$ & $\mathrm{H}_{2} \mathrm{O} ; \mathrm{KCl}$ & Coherent \\
\hline \multirow{6}{*}{$\mathrm{MgCl}_{2}-\mathrm{H}_{2} \mathrm{O}[21]$} & $\mathrm{H}_{2}^{2} \mathrm{O}$ & Coherent \\
\hline & $\mathrm{MgCl}_{2} \cdot 1_{2} \mathrm{H}_{2} \mathrm{O}$ & $"$ \\
\hline & $\mathrm{MgCl}_{2} .8 \mathrm{H}_{2} \mathrm{O}$ & " \\
\hline & $\mathrm{MgCl}_{2} \cdot 6 \mathrm{H}_{2} \mathrm{O}$ & " \\
\hline & $\mathrm{MgCl}_{2} \cdot 4 \mathrm{H}_{2} \mathrm{O}$ & $"$ \\
\hline & $\mathrm{MgCl}_{2 \cdot 2} \mathrm{H}_{2} \mathrm{O}$ & $"$ \\
\hline \multirow{4}{*}{$\mathrm{Na}_{2} \mathrm{SO} 4-\mathrm{H}_{2} \mathrm{O}[21]$} & $\mathrm{H}_{2} \mathrm{O}$ & Coherent \\
\hline & $\mathrm{Na}_{2} \mathrm{SO}_{4} \cdot 10 \mathrm{H}_{2} \mathrm{O}$ & Coherent when \\
\hline & $\mathrm{Na}_{2} \mathrm{SO}_{4} \cdot 7 \mathrm{H}_{2} \mathrm{O}$ & $\mathrm{T}<100^{\circ} \mathrm{C}$ \\
\hline & $\mathrm{Na}_{2} \mathrm{SO}_{4}$ & \\
\hline \multirow[t]{2}{*}{$\mathrm{K}_{2} \mathrm{SO}_{4}-\mathrm{H}_{2} \mathrm{O}[21]$} & $\mathrm{H}_{2} \mathrm{O} ; \mathrm{K}_{2} \mathrm{SO}_{4} \cdot \mathrm{H}_{2} \mathrm{O}$ & Coherent when \\
\hline & $\mathrm{K}_{2} \mathrm{SO}_{4}$ & $\mathrm{~T}<100^{\circ} \mathrm{C}$ \\
\hline \multirow{5}{*}{$\mathrm{MgSO}_{4}-\mathrm{H}_{2} \mathrm{O}[21]$} & $\mathrm{H}_{2} \mathrm{O}$ & Coherent \\
\hline & $\mathrm{Mg}_{2} \mathrm{SO}_{4} \cdot 7 \mathrm{H}_{2} \mathrm{O}$ & Coherent when \\
\hline & $\mathrm{MgSO}_{4} \cdot 6 \mathrm{H}_{2} \mathrm{O}$ & $\mathrm{T}<100^{\circ} \mathrm{C}$ \\
\hline & $\mathrm{MgSO}_{4} \cdot 4 \mathrm{H}_{2} \mathrm{O}$ & 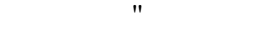 \\
\hline & $\mathrm{MgSO}_{4} \cdot \mathrm{H}_{2} \mathrm{O}$ & " \\
\hline \multirow[t]{4}{*}{$\mathrm{Na}_{2} \mathrm{SO}_{4}-\mathrm{MgSO}_{4}-\mathrm{H}_{2} \mathrm{O}$ [33] } & $\mathrm{Na}_{2} \mathrm{SO}_{4}$ & Partial coherent \\
\hline & $\mathrm{Na}_{2} \mathrm{SO}_{4} \cdot 10 \mathrm{H}_{2} \mathrm{O}$ & " \\
\hline & $\mathrm{MgSO}_{4} \cdot 7 \mathrm{H}_{2} \mathrm{O}$ & $"$ \\
\hline & $\mathrm{Na}_{2} \mathrm{SO}_{4} \mathrm{MgSO}_{4} \cdot 4 \mathrm{H}_{2} \mathrm{O}$ & " \\
\hline $\mathrm{NaCl}-\mathrm{KCl}-\mathrm{MgCl}_{2}-\mathrm{H}_{2} \mathrm{O}$ [25] & $\mathrm{NaCl} ; \mathrm{KCl}$ & Coherent \\
\hline
\end{tabular}

\section{REFERENCES}

1. L. Zayani. "Study of a Tunisian south brine, crystallization sequence and modelling", Doctorate thesis, Faculty of Sciences of Tunis, Tunisia (1999).

2. L. Joleaud. Geology of the Tunisian East and South. C. R. sommaire de la Soc. Geol. de France, No. 12, pp. 123-125 (1918).

3. R. Bourguignon. Extraction of brome and potash in Tunisia. Bull. Soc. Encouragement Industrie et Nature, Paris, No. 131, pp. 140-147 (1919).

4. L. Berthon. Minerals Industry in Tunisia, Imprimerie la Rapide, Tunis (1922). 
5. P. Bovis. Chim. Ind. 8, 693-695 (1922).

6. P. Bovis. Chim. Ind. 19, 937 (1928).

7. J. d'Ans. Die Lösungsgleichgewichte der Systeme der Salze ozeanischer Salzablagerungen., Verlagsges, für Ackerbau, M.B.H. Berlin (1933).

8. M. Solignac. Note on the sodium sulfate ore of the Tunisian South, Office National des Mines. La Charguia I, Tunis, Tunisia, RI 528 (1942).

9. Van't Hoff and Meyerhoffer (1905). Zur Bildung der Ozeanischen Salzblagerungen, Russian translation of Kurnakov, Leningrad, ONTI (1936).

10. E. Milokhoff. Contribution to geological knowledge of the chotts, Comptes. Proceedings of $9^{\text {th }}$ International Géological Conference 1952- Alger, Section 13, Fasc. 15, pp. 337-339 (1954).

11. Landoltt-Börnstein. Zahlenwerte und Funktionen, Lösungsgleichgewichte 1, Springer-Verlag, Berlin (1962); Physikalisch-chemische Tabellen.

12. H. Stephen and T. Stephen. Solubility of Inorganic and Organic Compounds, Macmillan, New York (1963).

13. W. F. Linke and A. Seidell. Solubilities: Inorganic and Metal-organic Compounds, $4^{\text {th }}$ ed., American Chemical Society, Washington, DC (1965).

14. S. Floridia. Report on Sebkhat el Melah of Zarzis. Office National des Mines. La Charguia I, Tunis, Tunisia, RI 513 (1968).

15. A. Aubry. Rev. Chim. Min. 8, 231-240 (1970).

16. J. P. Perthuisot. Study of Sebkhat el Kebira of Zarzis, CRAS Paris, 270, 1668-1671 (1970).

17. M. Abdeljaouad, A. Douiri, A. Touhami. Geology and exploitation of Sebkhat el Melah, Proceedings of the Seminary, Recherche scientifique et dévelopement des zones arides en Tunisie, à Tozeur. Office National des Mines. La Charguia I, Tunis, Tunisia, TN 103 (1979).

18. T. Hajeri. Study on the natural brines of the Tunisian South, DEA, Office National des Mines. La Charguia I, Tunis, Tunisia, TN 333 (1979).

19. M. Gueddari. Geochemistry of chott el Jerid brine, Doctorate thesis, Faculty of Sciences of Tunis, Tunisia (1980).

20. A. Chaabouni. Extraction of KCl from Chott el Jerid. DEA, Faculty of Sciences of Tunis, Tunisia (1980).

21. N. K. Guerfal. System: $\mathrm{K}^{+}, \mathrm{Na}^{+} / \mathrm{Cl}^{-}, \mathrm{SO}_{4}{ }^{2-}-\mathrm{H}_{2} \mathrm{O}$ at $10^{\circ} \mathrm{C}$, Doctorate thesis, Faculty of Sciences of Tunis, Tunisia (1981).

22. N. Kalai. Contribution to the study of the Tunisian south chotts brines. Doctorate thesis, Faculty of Sciences of Tunis, Tunisia (1986).

23. N. Kalai, N. Kbir Ariguib, M. Trabelsi. Thermochemica Acta, 111, 235-310 (1987).

24. H. Rouine. Sodium sulfate crystallization from Sebkhat. om Khialat, Office National des Mines. La Charguia I, Tunis, Tunisia, RI 656 (1987).

25. R. Cohen Adad and J. Lorimer. IUPAC Solubility Data Series. 47, Pergamon (1991).

26. D. B. H. Chehimi. Contribution to the study and the modeling of salts systems. Doctorate thesis, Faculty of Sciences of Tunis, Tunisia (1997).

27. R. Cohen Adad, M. T. Cohen Adad, D. Chehimi, A. Marrouche. In Thermodynamic Modeling and Materials Data Engineering, J.-P. Caliste, A. Truyol, J. H. Westbrook (Eds.), pp. 95-108. Springer-Verlag, Berlin (1998).

28. C. Djebali, L. Zayani, A. M'nif, R. Rokbani. J. Société Chimique Tunisie 4, 233-244 (1998).

29. A. M'nif, L. Zayani, R. Rokbani. J. Société Chimique Tunisie 4, $289-299$ (1998).

30. L. Zayani, R. Rokbani, M. Trabelsi-Ayadi. J. Therm. Anal. Calorim. 57, 575-585 (1999).

31. L. Zayani and R. Rokbani. J. Therm. Anal. Calorim. 59, 885-892 (2000).

32. A. M'nif and R. Rokbani. Asian J. Chem. 12, 58-68 (2000).

33. D. B. H. Chehimi, L. Zayani, R. Cohen Adad, M. T. Ayadi, N. K. Ariguib. "Modeling of phase diagrams applied to the systems $\mathrm{Na}^{+}, \mathrm{Mg}^{2+} / \mathrm{Cl}^{-}, \mathrm{SO}_{4}{ }^{2-}-\mathrm{H}_{2} \mathrm{O}$ and $\mathrm{Na}^{+}, \mathrm{K}^{+}, \mathrm{Mg}^{2+} / \mathrm{SO}_{4}{ }^{2-} \mathrm{H}_{2} \mathrm{O}$ ", P6 $9^{\text {th }}$ ISSP/IUPAC, Tunisia (2000). 
34. L. Zayani, D. B. H. Chehimi, R. Cohen Adad, R. Rokbani, M. T. Cohen Adad, N. K. Ariguib. "Geometrical principles for calculation of brines crystallization sequence", P30, ${ }^{\text {th }}$ ISSP/IUPAC, Tunisia (2000).

*Symbols used in Figs. 2 to 7:

$\mathrm{G}=\mathrm{H}_{2} \mathrm{O} ; \mathrm{NC}=\mathrm{NaCl} ; \mathrm{KC}=\mathrm{KCl} ; \mathrm{MC}=\mathrm{MgCl}_{2} ; \mathrm{NS}=\mathrm{Na}_{2} \mathrm{SO}_{4} ; \mathrm{KS}=\mathrm{K}_{2} \mathrm{SO}_{4} ; \mathrm{MS}=\mathrm{MgSO}_{4} ; \mathrm{NC} 2=\mathrm{NaCl}_{2} 2 \mathrm{H}_{2} \mathrm{O} ;$ MC6 $=\mathrm{MgCl}_{2} \cdot 6 \mathrm{H}_{2} \mathrm{O} ; \mathrm{KMC} 6=\mathrm{KClMgCl}_{2} \cdot 6 \mathrm{H}_{2} \mathrm{O} ; \mathrm{NS} 10=\mathrm{Na}_{2} \mathrm{SO}_{4} \cdot 10 \mathrm{H}_{2} \mathrm{O} ; \mathrm{KS} 1=\mathrm{K}_{2} \mathrm{SO}_{4} \cdot \mathrm{H}_{2} \mathrm{O} ; \mathrm{NS} 3 \mathrm{KS}=\mathrm{Na}_{2} \mathrm{SO}_{4} 3 \mathrm{~K}_{2} \mathrm{SO}_{4}$ 